\title{
Synthesis and Photophysical Properties of Neutral Luminescent Rhenium-Based Molecular Rectangles
}

\author{
T. Rajendran, ${ }^{\dagger}$ Bala. Manimaran, ${ }^{\dagger}$ Rong-Tang Liao, ${ }^{\dagger}$ Ren-Jay Lin, ${ }^{\ddagger}$ P. Thanasekaran, ${ }^{\dagger}$ \\ Gene-Hsiang Lee, ${ }^{\S}$ Shie-Ming Peng, ${ }^{\S}$ Yen-Hsiang Liu, ${ }^{\dagger}$ I-Jy Chang, ${ }^{*, \neq}$ S. Rajagopal, ${ }^{*,+, \| l}$ and \\ Kuang-Lieh Lu, ${ }^{*}$,
}

\begin{abstract}
Institute of Chemistry, Academia Sinica, Taipei 115, Taiwan, Department of Chemistry, National Taiwan Normal University, Taipei 117, Taiwan, Department of Chemistry, National Taiwan University, Taipei 107, Taiwan, and School of Chemistry, Madurai Kamaraj University, Madurai, 625 021, India
\end{abstract}

Received January 29, 2003

\begin{abstract}
A series of neutral luminescent molecular rectangles $\left[\left\{\operatorname{Re}(\mathrm{CO})_{3}(u \text {-bpy }) \operatorname{Br}\right\}\left\{\operatorname{Re}(\mathrm{CO})_{3}(u-\mathrm{L}) \operatorname{Br}\right\}\right]_{2}(1-4)$ having fac$\operatorname{Re}(\mathrm{CO})_{3} \mathrm{Br}$ as corners and 4,4'-bipyridine (bpy) as the bridging ligand on one side and other bipyridyl ligands of varying length $(L)$ on the other side have been synthesized and characterized. The crystal structure of 1 shows a rectangular cavity with the dimensions of $11.44 \times 7.21 \AA$. When the cavity size is tuned from 1 to 4 , a dimension of $11.4 \times 20.8 \AA$ could be achieved, as revealed by the molecular modeling. These rectangles exhibit luminescence in solution at room temperature. In particular, compound 4 containing 1,4-bis(4'-pyridylethynyl)benzene (bpeb) as bridging ligand shows the excited-state lifetime of $495 \mathrm{~ns}$. Fine-tuning of the cavity size of the rectangles improves their excited-state properties. These properties facilitate the study of excited-state electron-transfer reactions with electron acceptors and donors and host-guest binding. Crystallographic information: $1 \cdot 6 \mathrm{CH}_{3} \mathrm{COCH}_{3}$ is monoclinic, $P 2{ }_{1} / c$, with $a=12.0890(2), b=24.2982(2)$, and $c=12.8721(2) \AA, \beta=107.923(1)^{\circ}$, and $Z=2$.
\end{abstract}

\section{Introduction}

The ground- and excited-state properties of the organometallic complex $f a c-\left[\mathrm{ClRe}(\mathrm{CO})_{3} \mathrm{LL}\right]$, where $\mathrm{LL}$ is a diimine, and its derivatives have been extensively studied in the past 2 decades due to their potential for use in solar energy conversion and as sensors. ${ }^{1-12}$ These complexes are ideally

* To whom correspondence should be addressed. E-mail: lu@ chem.sinica.edu.tw (K.-L.L.). Fax: int. code + (2)27831237.

$\dagger$ Academia Sinica.

$\$$ National Taiwan Normal University.

$\S$ National Taiwan University.

"Madurai Kamaraj University.

(1) (a) Giordano, P. J.; Wrighton, M. S. J. Am. Chem. Soc. 1979, 101 2888. (b) Geoffroy, G. L.; Wrighton, M. S. Organometallic Photochemistry; Academic Press: New York, 1979.

(2) (a) Lees, A. J. Chem. Rev. 1987, 87, 711. (b) Sun, S. S.; Lees, A. J. Coord. Chem. Rev. 2002, 230, 171.

(3) (a) Stufkens, D. J. Comments Inorg. Chem. 1992, 13, 359. (b) Stufkens, D. J.; Vleck, A., Jr. Coord. Chem. Rev. 1998, 177, 127.

(4) Kalyanasundaram, K. Photochemistry of Polypyridine and Porphyrin Complexes; Academic Press: London, 1992.

(5) (a) Wallace, L.; Rillema, D. P. Inorg. Chem. 1993, 32, 3836. (b) Shaw, J. R.; Schmehl, R. H. J. Am. Chem. Soc. 1991, 113, 389.

(6) (a) Sacksteder, L.; Lee, M.; Demas, J. N.; DeGraff, B. A. J. Am. Chem. Soc. 1993, 115, 8230. (b) Zipp, A. P.; Sacksteder, L.; Streich, J.; Cook, A.; Demas, J. N.; DeGraff, B. A. Inorg. Chem. 1993, 32, 5629. (c) Spellane, P.; Watts, R. J. Inorg. Chem. 1993, 32, 5633. (d) Sacksteder, L.; Zipp, A. P.; Brown, E. A.; Streich, J.; Demas, J. N.; DeGraff, B. A. Inorg. Chem. 1990, 29, 4335.

6388 Inorganic Chemistry, Vol. 42, No. 20, 2003 suited for such applications since they display intense luminescence in the visible region and are stable to photodecomposition. In this decade much attention has been paid to transition-metal-directed self-assembly to construct many

(7) Balzani, V.; Juris, A.; Venturi, M.; Campagna, S.; Serroni, S. Chem. Rev. 1996, 96, 759.

(8) (a) Schanze, K. S.; MacQueen, D. B.; Perkins, T. A.; Cabana, L. A. Coord. Chem. Rev. 1993, 122, 63. (b) Schanze, K. S.; Walters, K. A. In Photoinduced electron transfer in metal-organic dyads; Ramamurthy, V., Schanze, K. S., Eds.; Marcel Dekker: New York, 1998; Vol. 2, pp 75-127.

(9) (a) Slone, R. V.; Benkstein, K. D.; Belanger, S.; Hupp, J. T.; Guzei, I. A.; Rheingold, A. L. Coord. Chem. Rev. 1998, 171, 221. (b) Slone, R. V.; Hupp, J. T. Inorg. Chem. 1997, 36, 5422. (c) Slone, R. V.; Hupp, J. T.; Stern, C. L.; Albrecht-Schmitt, T. E. Inorg. Chem. 1996, 35, 4096. (d) Walters, K. A.; Kim, Y. J.; Hupp, J. T. Inorg. Chem. 2002, 41, 2909.

(10) Shen, Y.; Sullivan, B. P. J. Chem. Educ. 1997, 74, 685

(11) (a) Leininger, S.; Olenyuk, B.; Stang, P. J. Chem. Rev. 2000, 100, 853. (b) Olenyuk, B.; Fechtenkotter, A.; Stang, P. J. J. Chem. Soc. Dalton Trans. 1998, 1707. (c) Stang, P. J.; Olenyuk, B. Acc. Chem. Res. 1997, 30, 502. (d) Swiegers, G. F.; Malefetse, T. J. Chem. Rev. 2000, $100,3483$.

(12) (a) Gianneschi, N. C.; Mirkin, C. A.; Zakharov, L. N.; Rheingold, A. L. Inorg. Chem. 2002, 41, 5326. (b) Mirkin, C. A.; Holliday, B. J. Angew. Chem., Int. Ed. 2001, 40, 2022. (c) Liu, X.; Eisenberg, A. H.; Stern, C. L.; Mirkin, C. A. Inorg. Chem. 2001, 40, 2940. (d) Holliday, B. J.; Farrell, J. R.; Mirkin, C. A.; Lam, K.-C.; Rheingold, A. L. J. Am. Chem. Soc. 1999, 121, 6316. (e) Farrell, J. R.; Mirkin, C. A.; Liable-Sands, L. M.; Rheingold, A. L. J. Am. Chem. Soc. 1998, 120, 11834.

10.1021/ic034099x CCC: $\$ 25.00$ @ 2003 American Chemical Society Published on Web 09/12/2003 
different supramolecular architectures such as molecular squares, boxes, helices, and many interesting three-dimensional structures. ${ }^{7-20}$ The rigid macrocycles based on cisbridging ligation of transition metals have tremendous promise in host - guest, inclusion, and molecular recognition chemistry. ${ }^{9-15}$ Recent interest is the synthesis and characterization of luminescent molecular squares containing a variety of bipyridyl groups between $\operatorname{Re}(\mathrm{I})$ centers. $^{9-12,16-18}$ Though the synthesis of several dozens of squares has been successfully demonstrated from many groups of workers, the reports on the $\operatorname{Re}(\mathrm{I})$-containing rectangles are relatively scarce. ${ }^{19,20}$ A rectangular cavity is reasonably expected to offer enhanced binding and selectivity particularly for planar aromatic guests. ${ }^{19 \mathrm{c}}$

We have initiated a systematic study on the synthesis of light-emitting neutral molecular rectangles, and the preliminary results have been reported. ${ }^{20 a}$ To improve the cavity size and luminescent properties of molecular rectangles, we have introduced acetylene, butadiyne, and 1,4-bis(ethynyl)benzene groups between two pyridine moieties in the ligand on one side while keeping 4,4'-bipyridine on the other side for the synthesis of $\operatorname{Re}(\mathrm{I})$-containing rectangles. In this report the details on the synthesis, characterization, photophysical properties, and host-guest interactions of the rectangles containing pyrazine (pz), 4,4'-dipyridylacetylene (dpa), 4,4'dipyridylbutadiyne (dpb), and 1,4-bis(4'-pyridylethynyl)benzene (bpeb) bridges are presented.

\section{Results and Discussion}

Synthesis and Characterization. The molecular rectangles $\left[\left\{\operatorname{Re}(\mathrm{CO})_{3}(\mu\right.\right.$-bpy $\left.) \mathrm{Br}\right\}\left\{\operatorname{Re}(\mathrm{CO})_{3}(\mu \text {-L) Br }\}\right]_{2}(\mathbf{1}, \mathrm{L}=\mathrm{pz}$;

(13) (a) Caulder, D. L.; Raymond, K. N. Acc. Chem. Res. 1999, 32, 975. (b) Caulder, D. L.; Raymond, K. N. J. Chem. Soc., Dalton Trans. 1999, 1185.

(14) (a) Lehn, J. M. Supramolecular Chemistry; VCH Publishers: New York, 1995. (b) Comprehensive Supramolecular Chemistry; Atwood, J. L., Davies, J. E. D., MacNicol, D. D., Vogtle, F., Lehn, J. M., Eds.; Pergamon: Oxford, U.K., 1996; Vols. 6 and 9. (c) Blanco, M. J.; Jimenez, M. C.; Chambron, J. C.; Heitz, V.; Linke, M.; Sauvage, J. P. Chem. Soc. Rev. 1999, 28, 293.

(15) (a) de Silva, A. P.; Gunaratne, H. Q. N.; Gunnlaugsson, T.; Huxley, A. J. M.; McCoy, C. P.; Rademacher, J. T.; Rice, T. E. Chem. Rev. 1997, 97, 1515 and references therein. (b) Chemosensors of Ion and Molecule Recognition; Desvergne, J. P., Czarnik, A. W., Eds.; Kluwer: Boston, MA, 1997.

(16) (a) Belanger, S.; Hupp, J. T.; Stern, C. L.; Slone, R. V.; Watson, D. F.; Carrell, T. G. J. Am. Chem. Soc. 1999, 121, 557. (b) Keefe, M. H.; Slone, R. V.; Hupp, J. T.; Czaplewski, K. F.; Snurr, R. Q.; Stern, C. L. Langmuir 2000, 16, 3964. (c) Sun, S. S.; Lees, A. J. J. Am. Chem. Soc. 2000, 122, 8956. (d). Sun, S. S.; Lees, A. J. Inorg. Chem. 1999, 38, 4181.

(17) Manimaran, B.; Rajendran, T.; Lee, F. Y.; Lin, S. C.; Lee, G. H.; Peng, S. M.; Chen, Y. J.; Lu, K. L. J. Chem. Soc., Dalton Trans. 2001, 3346.

(18) (a) Fujita, M.; Umemoto, K.; Yoshizawa, M.; Fujita, N.; Kusukawa, T.; Biradha, K. Chem. Commun. 2001, 509. (b) Fujita, M. Chem. Soc. Rev. 1998, 27, 417.

(19) (a) Benkstein, K. D.; Hupp, J. T.; Stern, C. L. Angew. Chem., Int. Ed. 2000, 39, 2891. (b) Benkstein, K. D.; Hupp, J. T.; Stern, C. L. Inorg. Chem. 1998, 37, 5404. (c) Benkstein, K. D.; Hupp, J. T.; Stern, C. L. J. Am. Chem. Soc. 1998, 120, 12982. (d) Woessner, S. M.; Helms, J. B.; Shen, Y.; Sullivan, B. P. Inorg. Chem. 1998, 37, 5406. (e) Hartmann, H.; Berger, S.; Winter, R.; Fiedler, J.; Kaim, W. Inorg. Chem. 2000, 39, 4977 .

(20) (a) Rajendran, T.; Manimaran, B.; Lee, F. Y.; Lee, G. H.; Peng, S. M.; Wang, C. M.; Lu, K. L. Inorg. Chem. 2000, 39, 2016. (b) Manimaran, B.; Rajendran, T.; Lu, Y. L.: Lee, G. H.; Peng, S. M.; Lu, K. L. J. Chem. Soc., Dalton Trans. 2001, 515.

\section{Scheme 1}
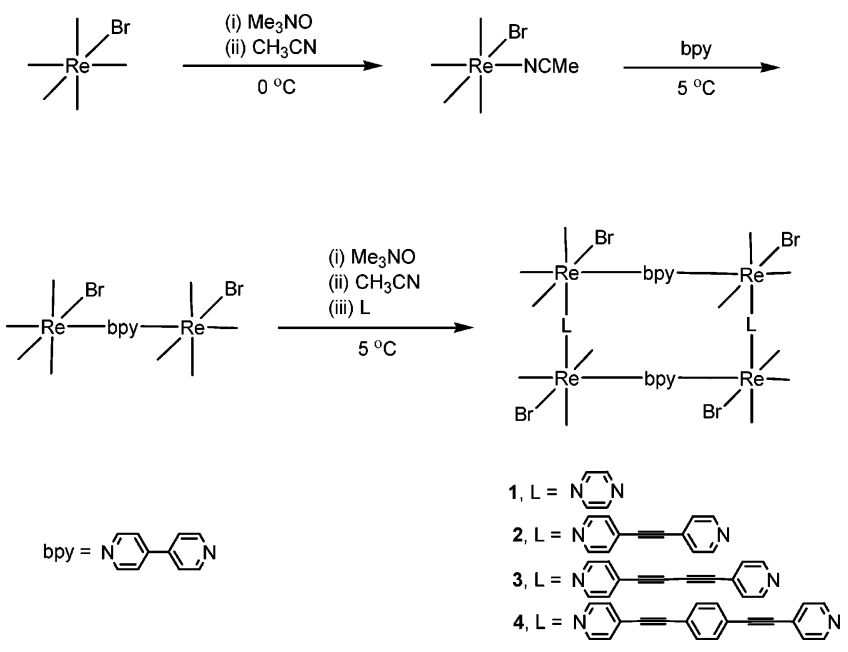

2, $\mathrm{L}=\mathrm{dpa} ; \mathbf{3}, \mathrm{L}=\mathrm{dpb} ; \mathbf{4}, \mathrm{L}=$ bpeb) were synthesized as shown in Scheme 1. Treatment of $\operatorname{Re}(\mathrm{CO})_{5} \mathrm{Br}$ with 1 equiv of $\mathrm{Me}_{3} \mathrm{NO}$ in the presence of $\mathrm{CH}_{3} \mathrm{CN}$ at $0{ }^{\circ} \mathrm{C}$ gave $\mathrm{Re}(\mathrm{CO})_{4^{-}}$ (NCMe)Br, which on reaction with 4,4'-bipyridine (bpy) afforded $\left\{\operatorname{Re}(\mathrm{CO})_{4} \mathrm{Br}\right\}_{2}(\mu$-bpy $)$. Further treatment of the bimetallic edge $\left\{\operatorname{Re}(\mathrm{CO})_{4} \mathrm{Br}\right\}_{2}\left(\mu\right.$-bpy) with 2 equiv of $\mathrm{Me}_{3}-$ $\mathrm{NO}$ at $5{ }^{\circ} \mathrm{C}$ followed by addition of pyrazine or acetylenecontaining bipyridyl ligands afforded the molecular rectangles $\mathbf{1} \mathbf{- 4}$.

The molecular rectangles $\mathbf{1 - 4}$ were characterized by a variety of analytical techniques such as IR, NMR, FAB-mass, and elemental analysis. The ${ }^{1} \mathrm{H}$ NMR spectrum of $\mathbf{1}$ showed two sets of signals in a 3:1 ratio for both the pyrazine and the pyridyl groups of the bpy ligand, indicating that $\mathbf{1}$ exists as two isomeric forms in solution at ambient temperature. Compared to the free ligands these signals were shifted toward low field due to the formation of new coordination bonds between the nitrogen-containing ligands and the $\mathrm{Re}$ metal centers. ${ }^{21}$ The FAB mass spectrum of $\mathbf{1}$ showed the molecular ion peak at $\mathrm{m} / \mathrm{z} 1880$ whose experimental isotope pattern matches very closely with that calculated.

By use of the single-crystal X-ray diffraction method, we obtained solid evidence to support the structure of complex 1. An ORTEP diagram of $\mathbf{1}$ is shown in Figure 1, and its pertinent crystallographic data are given in Tables 1 and 2 . The core geometry can be viewed as a molecular rectangle in which two $\mathrm{Br}(\mathrm{CO})_{4} \mathrm{Re}$-bpy- $\mathrm{Re}(\mathrm{CO})_{4} \mathrm{Br}$ edges are bridged by two pyrazine moieties with the cavity dimension of 11.44 $\times 7.21 \AA . \operatorname{Br}(1)$ and $\operatorname{Br}(2)$ are disordered with $\mathrm{CO}$ group in $73 / 27$ occupancy, which is corroborated by the isomeric ${ }^{1} \mathrm{H}$ NMR spectral pattern of $\mathbf{1}$. An infinite number of open-end channels are observed from the packing diagram because of the effective $\pi$ stacking of the aromatic rings of the molecules (Figure 2).

The result of the molecular modeling study of $\mathbf{1}-\mathbf{4}$ reveals that a cavity dimension of $11.4 \times 20.8 \AA$ could be achieved by the proper selection of the acetylene-containing bipyridyl ligands (Table 3). The large cavity dimension promises

(21) Kuehl, C. J.; Huang, S. D.; Stang, P. J. J. Am. Chem. Soc. 2001, 123 9634. 


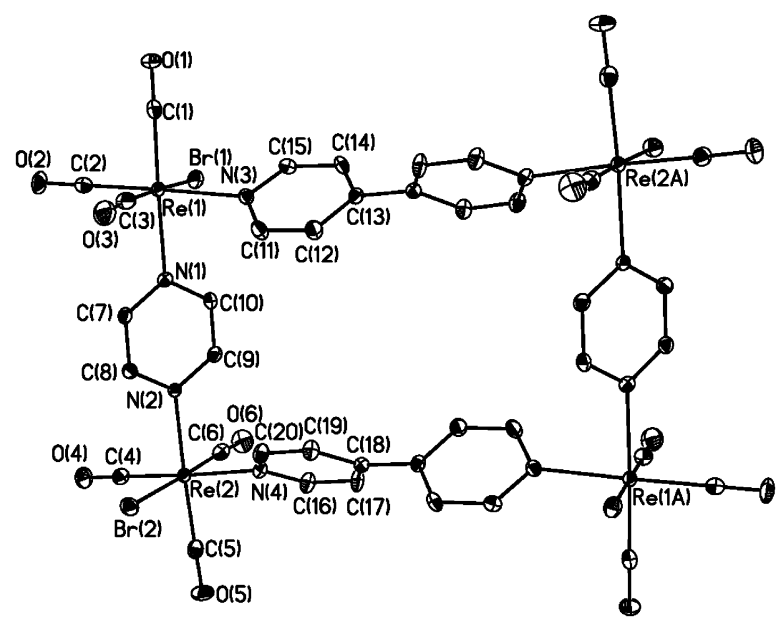

Figure 1. ORTEP diagram of 1.

Table 1. Crystal and Structure Refinement Data for $\left[\left\{\operatorname{Re}(\mathrm{CO})_{3}(\mu \text {-bpy }) \mathrm{Br}\right\}\left\{\operatorname{Re}(\mathrm{CO})_{3}(\mu-\mathrm{pz}) \mathrm{Br}\right\}\right]_{2} \cdot 6 \mathrm{CH}_{3} \mathrm{COCH}_{3}, \mathbf{1} \cdot 6 \mathrm{CH}_{3} \mathrm{COCH}_{3}$

\begin{tabular}{|c|c|}
\hline formula & $\mathrm{C}_{58} \mathrm{H}_{60} \mathrm{Br}_{4} \mathrm{~N}_{8} \mathrm{O}_{18} \mathrm{Re}_{4}$ \\
\hline fw & 2221.58 \\
\hline cryst syst & monoclinic \\
\hline space group & $P 2_{1} / c$ \\
\hline$a, \AA$ & $12.0890(2)$ \\
\hline$b, \AA$ & $24.2982(2)$ \\
\hline$c, \AA$ & $12.8721(2)$ \\
\hline$\beta, \operatorname{deg}$ & $107.923(1)$ \\
\hline$V, \AA^{3}$ & $3597.57(9)$ \\
\hline Z & 2 \\
\hline cryst dimens, mm & $0.35 \times 0.18 \times 0.12$ \\
\hline$\rho_{\text {calcd }}, \mathrm{Mg} / \mathrm{m}^{3}$ & 2.051 \\
\hline$\mu($ Mo K $\alpha), \mathrm{mm}^{-1}$ & 8.998 \\
\hline range of transm factors & $0.2767-0.4921$ \\
\hline data/restraints/params & $7285 / 0 / 451$ \\
\hline $\mathrm{R} 1(I>2 \sigma(I))$ & 0.0356 \\
\hline wR2 (all data) & 0.0724 \\
\hline
\end{tabular}

Table 2. Selected Bond Distances ( $\AA$ ) and Bond Angles (deg) for $\mathbf{1}$

\begin{tabular}{llll}
\hline \multicolumn{4}{c}{ (a) Bond Distances $(\AA)$} \\
$\operatorname{Re}(1)-\mathrm{Br}(1)$ & $2.5694(14)$ & $\operatorname{Re}(1)-\mathrm{C}(1)$ & $1.929(7)$ \\
$\operatorname{Re}(1)-\mathrm{C}(2)$ & $1.922(6)$ & $\operatorname{Re}(1)-\mathrm{C}(3)$ & $1.92(2)$ \\
$\operatorname{Re}(1)-\mathrm{N}(1)$ & $2.212(5)$ & $\operatorname{Re}(1)-\mathrm{N}(3)$ & $2.221(5)$ \\
$\operatorname{Re}(2)-\mathrm{Br}(2)$ & $2.5873(13)$ & $\mathrm{Re}(2)-\mathrm{C}(4)$ & $1.919(6)$ \\
$\operatorname{Re}(2)-\mathrm{C}(5)$ & $1.924(7)$ & $\mathrm{Re}(2)-\mathrm{C}(6)$ & $1.917(14)$ \\
$\operatorname{Re}(2)-\mathrm{N}(2)$ & $2.212(4)$ & $\mathrm{Re}(2)-\mathrm{N}(4)$ & $2.218(5)$ \\
$\mathrm{C}(1)-\mathrm{O}(1)$ & $1.146(7)$ & $\mathrm{C}(2)-\mathrm{O}(2)$ & $1.153(7)$ \\
$\mathrm{C}(3)-\mathrm{O}(3)$ & $1.16(3)$ & $\mathrm{C}(4)-\mathrm{O}(4)$ & $1.153(7)$ \\
$\mathrm{C}(5)-\mathrm{O}(5)$ & $1.149(7)$ & $\mathrm{C}(6)-\mathrm{O}(6)$ & $1.17(2)$
\end{tabular}

\begin{tabular}{lccc}
\multicolumn{5}{c}{ (b) Bond Angles (deg) } \\
$\mathrm{N}(1)-\operatorname{Re}(1)-\mathrm{N}(3)$ & $84.5(2)$ & $\mathrm{C}(1)-\operatorname{Re}(1)-\mathrm{N}(1)$ & $178.0(2)$ \\
$\mathrm{C}(3)-\operatorname{Re}(1)-\mathrm{N}(1)$ & $90.5(10)$ & $\mathrm{C}(2)-\operatorname{Re}(1)-\mathrm{N}(1)$ & $94.1(2)$ \\
$\mathrm{C}(3)-\operatorname{Re}(1)-\mathrm{N}(3)$ & $92.6(10)$ & $\mathrm{C}(2)-\operatorname{Re}(1)-\mathrm{N}(3)$ & $178.6(2)$ \\
$\mathrm{C}(1)-\operatorname{Re}(1)-\mathrm{N}(3)$ & $93.6(2)$ & $\mathrm{C}(1)-\operatorname{Re}(1)-\operatorname{Br}(1)$ & $93.2(2)$ \\
$\mathrm{C}(3)-\operatorname{Re}(1)-\mathrm{Br}(1)$ & $177.3(10)$ & $\mathrm{C}(2)-\operatorname{Re}(1)-\operatorname{Br}(1)$ & $90.9(2)$ \\
$\mathrm{N}(1)-\operatorname{Re}(1)-\mathrm{Br}(1)$ & $87.21(12)$ & $\mathrm{N}(3)-\operatorname{Re}(1)-\mathrm{Br}(1)$ & $88.67(12)$ \\
$\mathrm{C}(6)-\operatorname{Re}(2)-\mathrm{N}(2)$ & $90.5(5)$ & $\mathrm{C}(5)-\operatorname{Re}(2)-\mathrm{N}(2)$ & $175.3(2)$ \\
$\mathrm{C}(6)-\operatorname{Re}(2)-\mathrm{N}(4)$ & $91.5(5)$ & $\mathrm{C}(4)-\operatorname{Re}(2)-\mathrm{N}(4)$ & $177.6(2)$ \\
$\mathrm{C}(5)-\operatorname{Re}(2)-\mathrm{N}(4)$ & $93.5(2)$ & $\mathrm{C}(6)-\operatorname{Re}(2)-\operatorname{Br}(2)$ & $178.4(5)$ \\
$\mathrm{C}(4)-\operatorname{Re}(2)-\mathrm{Br}(2)$ & $91.8(2)$ & $\mathrm{C}(5)-\operatorname{Re}(2)-\mathrm{Br}(2)$ & $89.8(2)$ \\
$\mathrm{N}(2)-\operatorname{Re}(2)-\operatorname{Br}(2)$ & $87.91(11)$ & $\mathrm{N}(4)-\operatorname{Re}(2)-\operatorname{Br}(2)$ & $88.65(12)$
\end{tabular}

interesting host - guest interactions. Since $\mathbf{1} \mathbf{- 4}$ contain large cavities, the solvent molecules such as acetone are present inside them and could not be removed completely under vacuum at room temperature for several hours.

Ground-State Properties. Table 4 summarizes the absorption spectral data of rectangles $\mathbf{1}-\mathbf{4}$ in comparison with squares $\left[\operatorname{Re}(\mathrm{CO})_{3}(\mu-\mathrm{pz}) \mathrm{Cl}\right]_{4}(\mathbf{5}),\left[\operatorname{Re}(\mathrm{CO})_{3}(\mu \text {-bpy }) \mathrm{Cl}\right]_{4}(\mathbf{6})$,

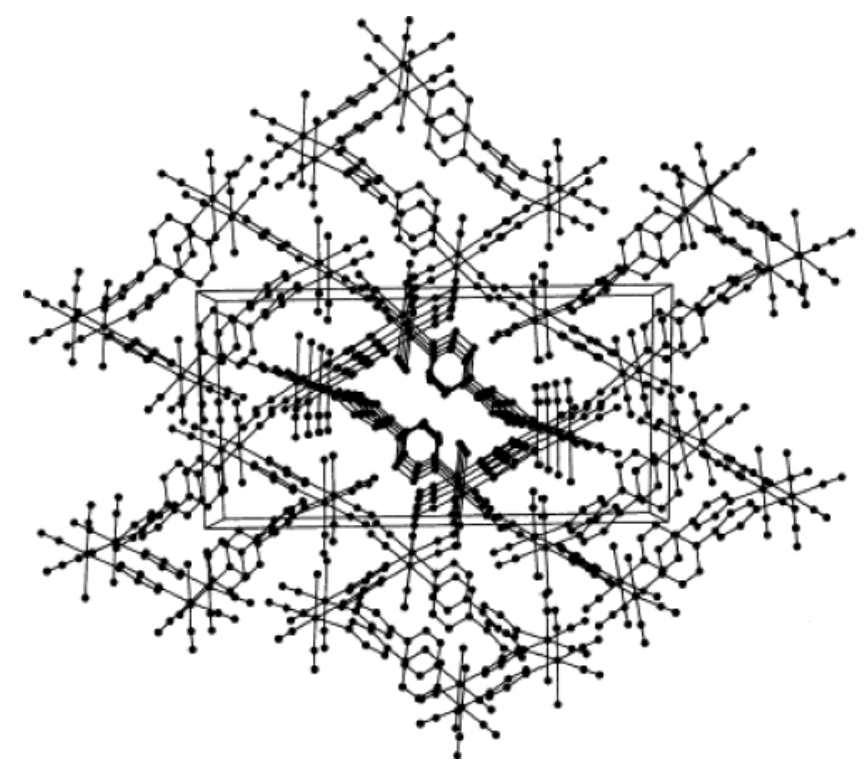

Figure 2. Packing diagram of $\mathbf{1}$.

Table 3. Molecular Modeling Data for Interatomic Distances (Re $\cdots \cdot R e)$ in $1-4$

\begin{tabular}{cccc}
\hline rectangle & $\mathrm{Re}-\mathrm{bpy}-\mathrm{Re}(\AA)$ & $\mathrm{Re}-\mathrm{L}-\mathrm{Re}(\AA)$ & $\mathrm{L}^{b}$ \\
\hline $\mathbf{1}$ & $11.4(11.440)^{a}$ & $7.19(7.214)^{a}$ & $\mathrm{pz}$ \\
$\mathbf{2}$ & 11.4 & 14.0 & $\mathrm{dpa}$ \\
$\mathbf{3}$ & 11.4 & 16.6 & $\mathrm{dpb}$ \\
$\mathbf{4}$ & 11.4 & 20.8 & $\mathrm{bpeb}$
\end{tabular}

${ }^{a}$ From X-ray structure analysis. ${ }^{b}$ bpy $=4,4^{\prime}$-bipyridine; $\mathrm{pz}=$ pyrazine; $\mathrm{dpa}=4,4^{\prime}$-dipyridylacetylene; $\mathrm{dpb}=4,4^{\prime}$-dipyridylbutadiyne; $\mathrm{bpeb}=1,4$ bis(4'-pyridylethynyl)benzene.

Table 4. Absorption and Emission Spectral and Excited-State Lifetime Data for $\mathrm{Re}(\mathrm{I})$ Compounds and Ligands in $\mathrm{CH}_{2} \mathrm{Cl}_{2}$ at $298 \mathrm{~K}$

\begin{tabular}{llcc}
\hline compd & \multicolumn{1}{c}{ abs $\lambda_{\max }, \mathrm{nm}$} & emission $\lambda_{\max }, \mathrm{nm}$ & lifetime $\tau, \mathrm{ns}$ \\
\hline $\mathbf{1}$ & 252,336 & 606 & 86 \\
$\mathbf{2}$ & 259,352 & 611 & 86 \\
$\mathbf{3}$ & $259,323,357$ & 616 & 72 \\
$\mathbf{4}$ & 260,351 & 616 & 495 \\
$\mathbf{5}^{c}$ & 274,396 & 682 & 54 \\
$\mathbf{6}^{c}$ & 248,348 & 632 & 134 \\
$\mathbf{7}^{d}$ & $322,360^{a}$ & $635^{a}$ & $39^{a}$ \\
$\mathbf{8}^{c}$ & 248,314 & 585 & 1670 \\
$\mathbf{9}^{e}$ & $251,262,288,302,322,345$ & 612 & 100 \\
bpy & 240,265 & $b$ & \\
dpa & $263,276,293$ & $b$ & \\
dpb & $245,256,285,304,325$ & $b$ & \\
bpeb & 319,339 & $b$ & \\
pz & $261,270,313$ & $b$ &
\end{tabular}

${ }^{a}$ Measurements taken in THF. ${ }^{b}$ No detectable emission. ${ }^{c}$ Reference $9 \mathrm{c}$. ${ }^{d}$ Reference $16 \mathrm{~d} .{ }^{e}$ Reference 23.

and $\left[\operatorname{Re}(\mathrm{CO})_{3}(\mu-\mathrm{dpb}) \mathrm{Cl}\right]_{4}(7)$, corners $\operatorname{Re}(\mathrm{CO})_{3}(\mathrm{bpy})_{2} \mathrm{Cl}(\mathbf{8})$ and $\mathrm{Re}(\mathrm{CO})_{3}(\mathrm{dpb})_{2} \mathrm{Cl}(\mathbf{9})$, and the ligands (Chart 1). Figure 3 compares the absorption spectra of rectangle 4 and the free ligands bpy and bpeb. The electronic absorption spectra of rectangles 1-4 exhibit two main features: the high-energy band in the near-UV region $(\sim 260 \mathrm{~nm})$ is assigned to the ligand centered $\pi-\pi^{*}$ transition, and the low-energy band, to the metal-to-ligand charge transfer (MLCT) transition. ${ }^{1,4,22}$ In the rectangle 3 , the lowest energy band is solely of MLCT character similar to square 7. It is noted that the MLCT bands

(22) Meyer, T. J. Pure Appl. Chem. 1986, 58, 1193.

6390 Inorganic Chemistry, Vol. 42, №. 20, 2003 


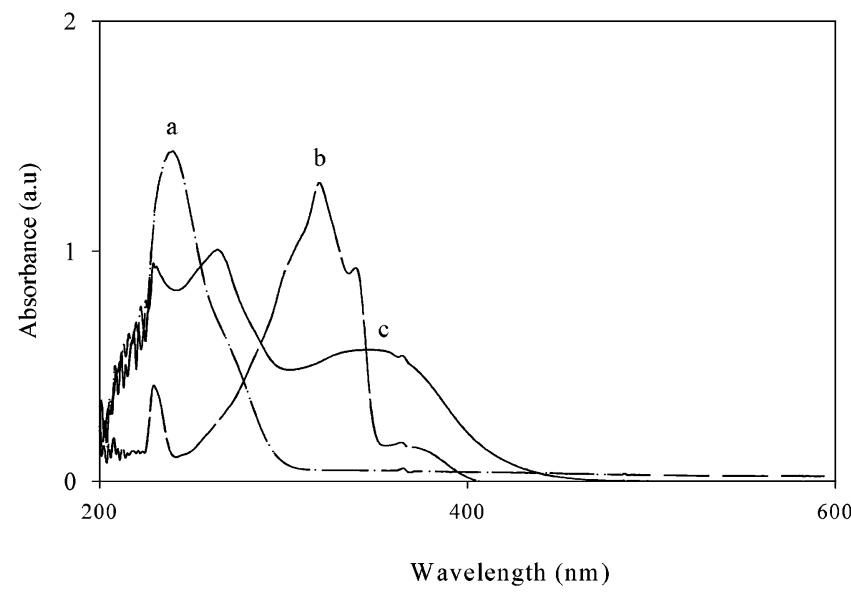

Figure 3. Absorption spectra of (a) 4,4'-bipyridine (bpy), (b) 1,4-bis(4'pyridylethynyl)benzene (bpeb), and (c) $\left[\left\{\operatorname{Re}(\mathrm{CO})_{3}(\mu\right.\right.$-bpy) $\mathrm{Br}\}\left\{\operatorname{Re}(\mathrm{CO})_{3}(\mu\right.$ bpeb)Br\} $]_{2}$ (4) in $\mathrm{CH}_{2} \mathrm{Cl}_{2}$.

\section{Chart 1}
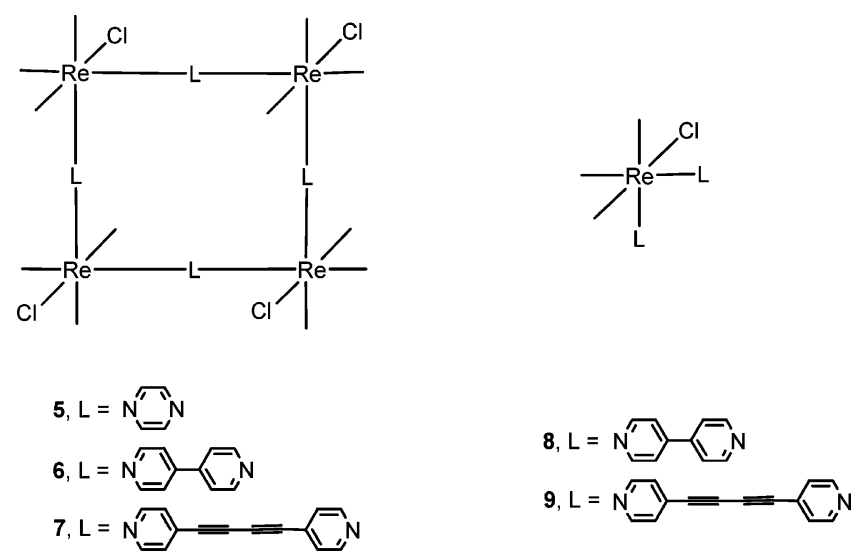

of rhenium complexes are insensitive to the variation of the halide ${ }^{24}$ The absorption data for $\mathbf{1 - 4}$ show that the substitution of pz by dpa, dpb, and bpeb leads to a red shift, but the introduction of bpeb in place of dpb does not lead to substantial change in the absorption spectrum of the rectangle. On the other hand, if we compare the rectangle $\mathbf{3}$ with square 7, both of them have a peak near $320 \mathrm{~nm}$ but an additional peak is obtained at $357 \mathrm{~nm}$ for $\mathbf{3}$ and at $360 \mathrm{~nm}$ for $\mathbf{7}$. If we compare $\mathbf{3}$ and $\mathbf{6}$, two MLCT peaks are observed for 3 at 323 and $357 \mathrm{~nm}$ but one peak for $\mathbf{6}$ at $348 \mathrm{~nm}$, whereas the corners 8 and $\mathbf{9}$ have absorption maxima at 316 and $342 \mathrm{~nm}$, respectively. Thus, we can assign the peak at $323 \mathrm{~nm}$ to $\operatorname{Re}(\mathrm{I}) \rightarrow$ bpy and $357 \mathrm{~nm}$ to $\operatorname{Re}(\mathrm{I}) \rightarrow$ dpb. In a comparison of $\mathbf{3}$ and $\mathbf{4}$, the $\lambda_{\max }$ value of $\mathbf{4}$ at $351 \mathrm{~nm}$ may be assigned to the MLCT transition $\operatorname{Re}(\mathrm{I}) \rightarrow$ bpeb.

Excited-State Properties. Maxima of emission spectra $\left(\lambda_{\max }{ }^{\mathrm{em}}\right)$ and excited-state lifetime $(\tau)$ of rectangles, squares, and corners are collected in Table 4 . The broad luminescence spectra of rectangles 2-4 (Figure 4) indicate that the luminescence originates from the lowest ${ }^{3} \mathrm{MLCT}$ state. The assignment of the lowest emitting level as MLCT in character is based on the position and shape of the emission band and the emission lifetime which are consistent with those

(23) Sun, S. S.; Anspach, J. A.; Lees, A. J.; Zavalij, P. Y. Organometallics 2002, 21, 685 .

(24) Giordano, P. J.; Wrighton, M. S. J. Am. Chem. Soc. 1979, 101, 2888.

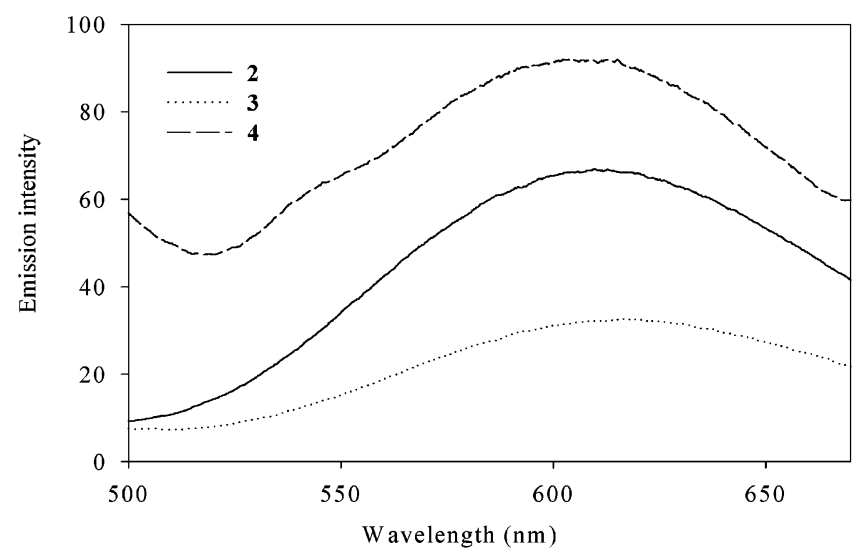

Figure 4. Luminescence spectra of molecular rectangles $\mathbf{2}-\mathbf{4}$ in $\mathrm{CH}_{2} \mathrm{Cl}_{2}$ at $298 \mathrm{~K}$.

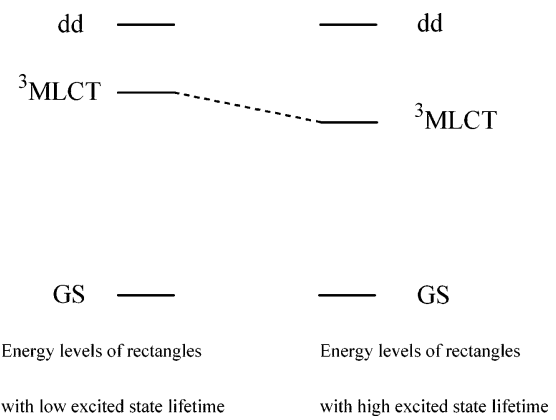

Figure 5. Energy level diagram of $\operatorname{Re}(\mathrm{I})$ rectangles.

previously reported for similar complexes assigned as MLCT emitters. ${ }^{5-10,16,19,20}$ Similar to the observation in the absorption spectra, the emission maxima of rectangles $\mathbf{1 - 4}$ are slightly shifted to lower energy while the conjugation of the ligand is extended. The emission spectra of rectangles $\mathbf{2 - 4}$ have also been recorded at $77 \mathrm{~K}$, and the emission maxima $\left(\lambda_{\max } \mathrm{em}\right.$ $=542,526$, and $536 \mathrm{~nm}$ for $\mathbf{2 - 4}$, respectively) are shifted to blue compared to the values at $298 \mathrm{~K}$ as observed with other metal complexes. ${ }^{25}$ These $\lambda_{\max }{ }^{\mathrm{em}}$ values at $77 \mathrm{~K}$ correspond to the energy of the $0-0$ transition and of ${ }^{3} \mathrm{MLCT}$ state and have been used in the estimation of excited-state redox potentials in combination with ground-state redox potentials (vide infra).

Though the emission lifetime of rectangles $\mathbf{1}-\mathbf{3}$ is similar, it is very high for 4 . As far as $\mathrm{Ru}(\mathrm{II})$ and $\mathrm{Re}(\mathrm{I})$ complexes are concerned, the lifetime of ${ }^{3} \mathrm{MLCT}$ is controlled by its energy. ${ }^{26}$ If the ${ }^{3} \mathrm{MLCT}$ state is close to the ${ }^{3} \mathrm{MC}$ state, the deactivation may take place via ${ }^{3} \mathrm{MC}$ which is nonemissive (Figure 5). If the ${ }^{3} \mathrm{MLCT}$ state is close to the ground state, according to the energy gap law, nonradiative decay is facile. Emission spectra recorded at $77 \mathrm{~K}$ show that the ${ }^{3} \mathrm{MLCT}$ level of rectangle $\mathbf{4}$ falls between $\mathbf{2}$ and $\mathbf{3}$. Thus, the probable explanation for the long lifetime of $\mathbf{4}$ compared to $\mathbf{2}$ and $\mathbf{3}$ with the available emission spectral data is that the ${ }^{3} \mathrm{MLCT}$ state of $\mathbf{4}$ is suitably positioned in such a way that it is away from ${ }^{3} \mathrm{MC}$ as well as from the ground state. A possible

(25) (a) Nieuwenhuis, H. A.; Stufkens, D. J.; Vlcek, A., Jr. Inorg. Chem 1995, 34, 3879. (b) Grosshenny, V.; Harriman, A.; Romero, F. M.; Ziessel, R. J. Phys. Chem. 1996, 100, 17472.

(26) Anderson, P. A.; Keene, F. R.; Meyer, T. J.; Moss, J. A.; Strouse, G. F.; Treadway, J. A. J. Chem. Soc., Dalton Trans. 2002, 3820. 
Rajendran et al.

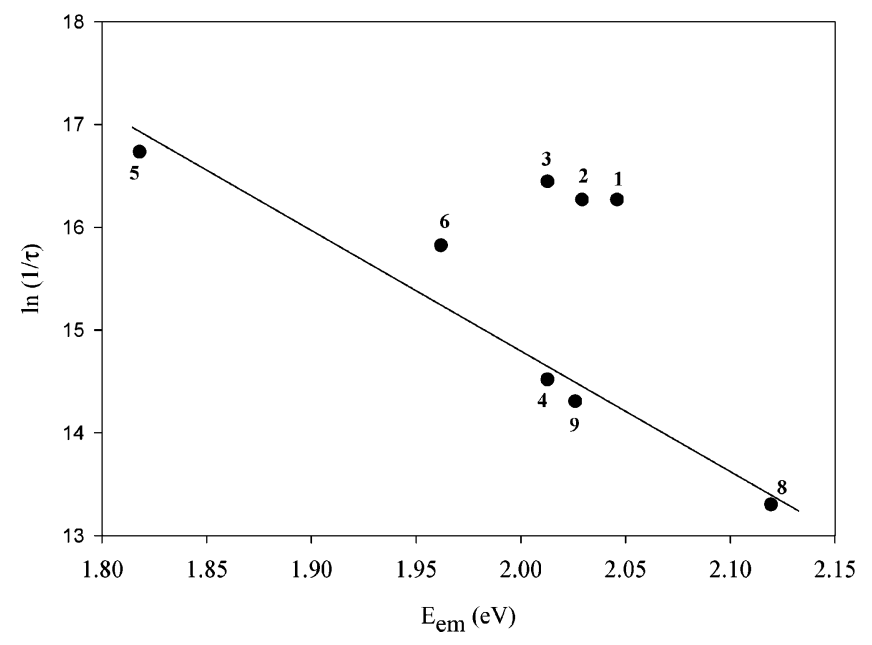

Figure 6. Energy-gap plot for molecular rectangles 1-4, squares 5 and $\mathbf{6}$, and corners $\mathbf{8}$ and $\mathbf{9}$. Excited-state lifetime data were obtained in deoxygenated $\mathrm{CH}_{2} \mathrm{Cl}_{2}$ at $298 \mathrm{~K}$.

alternative explanation for the long lifetime of $\mathbf{4}$ compared to $\mathbf{1}-\mathbf{3}$ is the involvement of the extended $\pi$ system of the bpeb ligand.

To gain insight into the excited-state lifetime of rectangles 1-4 an energy-gap plot has been constructed. The rates of decay of emissive excited states of $\operatorname{Re}(\mathrm{I})$ complexes, i.e., lifetime $(\tau)$, are typically controlled by nonradiative decay process. Figure 6 shows a plot of $\ln (1 / \tau)$ vs $E_{\mathrm{em}}$ for the rectangles 1-4, squares 5 and 6 , and corners 8 and 9 in $\mathrm{CH}_{2^{-}}$ $\mathrm{Cl}_{2}$. An analysis of the nonradiative decay rates for all complexes showed that the nonradiative decay rate constant is increased when the excited-state energy decreased. A linear relationship of $\ln (1 / \tau)$ vs $E_{\text {em }}$ with a correlation of 0.940 has been observed for rectangle $\mathbf{4}$ along with squares and corners. This effect can be understood in terms of the energy-gap law. ${ }^{27,28}$ Deviation from a linear relation between $\ln (1 / \tau)$ vs $E_{\text {em }}$ occurs for complexes $\mathbf{1 - 3}$ in which the vibrational modes of deactivation is sensitive to nonradiative decay. Whereas 4 minimizes the rate of nonradiative decay and hence it has a long excited-state lifetime. Thus by modulation of the nature of the ligand, design of a neutral molecular rectangle with sufficiently long triplet lifetime and large cavity can be achieved.

Electrochemical Properties. The measured cyclic voltammetric data for the rectangles 1-4, squares 5-7, and corners 8 and 9 are collected in Table 5. The rectangles $\mathbf{2 - 4}$ in $\mathrm{CH}_{2} \mathrm{Cl}_{2}$ show two reduction waves and three oxidation waves. The first reduction wave at around $-1.0 \mathrm{~V}$ can be assigned to the reduction of the non-bpy ligand, and the second reduction, to the bpy ligand. The ligand-centered reduction potential of the rectangles is much lower than those observed for free ligands..$^{29}$ The complexation of the ligand to the metal usually stabilizes the $\pi^{*}$ level in the ligand and lowers the energy of the $\pi^{*}$ orbital.

The first oxidation of the rectangles $\mathbf{2 - 4}$ around $0.4 \mathrm{~V}$ may be assigned to the oxidation of bromide ion. ${ }^{30}$ The

(27) Strouse, G. F.; Schoonover, J. R.; Duesing, R.; Boyde, S.; Jones, W. E., Jr.; Meyer, T. J. Inorg. Chem. 1995, 34, 473.

(28) Casper, J. V.; Meyer, J. V. J. Phys. Chem. 1983, 87, 952.

(29) Shaver, R. J.; Rillema, D. P. Inorg. Chem. 1992, 31, 4101.
Table 5. Ground-State Electrochemical Potentials of 1-9

\begin{tabular}{clcc}
\hline compd & solvent & $E_{\text {ox }}, \mathrm{V}\left(\Delta E_{\mathrm{p}}, \mathrm{mV}\right)$ & $E_{\text {red }}, \mathrm{V}\left(\Delta E_{\mathrm{p}}, \mathrm{mV}\right)$ \\
\hline $\mathbf{1}$ & acetonitrile & +1.05 & -1.446 \\
$\mathbf{2}$ & dichloromethane & +0.45 & -1.606 \\
& & $+1.35(160)$ & $-0.94(\mathrm{i})$ \\
& & +1.70 & $-1.176(\mathrm{i})$ \\
$\mathbf{3}$ & dichloromethane & $+0.35(\mathrm{i})$ & $-1.07(\mathrm{i})$ \\
& & $+1.35(191)$ & $-1.54(\mathrm{i})$ \\
$\mathbf{4}$ & \multirow{2}{*}{ dichloromethane } & $+1.64(53)$ & \\
& & $+0.36(\mathrm{i})$ & $-1.06(\mathrm{i})$ \\
$\mathbf{5}$ & acetonitrile & $+1.35(133)$ & $-1.40(122)$ \\
& & $+1.58(129)$ & -0.92 \\
$\mathbf{6}$ & acetonitrile & +1.35 & -1.23 \\
& & & -1.15 \\
$\mathbf{7}$ & tetrahydrofuran & & -1.26 \\
$\mathbf{8}$ & acetonitrile & +1.36 & $-1.70(\mathrm{i})$ \\
$\mathbf{9}$ & dichloromethane & $+1.09(\mathrm{i})$ & -1.67 \\
& & & $-1.69(\mathrm{i})$ \\
& &
\end{tabular}

quasireversible oxidation waves observed in the range 1.35$1.70 \mathrm{~V}$ may be attributed to the oxidation of the metal centers present in the rectangle. This redox behavior of these rectangles can be exploited in their utilization as electron donors in the efficient electron-transfer reactions with electron acceptors, quinones, and nitroaromatics and as electron acceptors with aromatic amines. ${ }^{31}$

Luminescence Quenching Studies. Recently it has been established that luminescent compounds with internal cavities find potential applications in host-guest chemistry, in molecular recognition, and as sensors..$^{9-21,32-34}$ Since the rectangles 1-4 contain a large cavity and are luminescent, they can be tested for host-guest interactions. To check the ability of 1-4 to act as hosts, we have studied the reactions of these rectangles with several nitroaromatics and quinones, good electron acceptors, and aromatic amines, electron donors. Interestingly, these substrates quench the luminescence of the rectangles efficiently and have quenching rate constants $\left(k_{\mathrm{q}}\right)$ in the range $3.0 \times 10^{7}-6.2 \times 10^{11} \mathrm{M}^{-1} \mathrm{~s}^{-1}$ $\left(k_{\mathrm{q}}\right.$ values have been calculated from Stern-Volmer plots using the luminescence intensity and lifetime data). The decrease in the emission intensity of the rectangle 3 with the increase in the concentration of the quencher $(1,2-$ chloranil) is shown in Figure 7. The $k_{\mathrm{q}}$ values for the quenching of 2-4 with several quinones, nitroaromatics, and amines and the sample Stern-Volmer plots are given in the Supporting Information (Table T6 and Figure F4). It is important to point out that though the Stern-Volmer plots

(30) (a) Musie, G.; Reibenspies, J. H.; Darensbourg, M. Y. Inorg. Chem. 1998, 37, 302. (b) Goodman, D. C.; Farmer, P. J.; Darensbourg, M. Y.; Reibenspies, J. H. Inorg. Chem. 1996, 35, 4989.

(31) Rajendran, T.; Manimaran, B.; Liao, R.-T.; Liu, Y.-H.; Thanasekaran, P.; Lin, R.-J.; Chang, I.-J.; Rajagopal, S.; Lu, K.-L. Manuscript in preparation.

(32) Aoyama, Y.; Asakawa, M.; Matsui, Y.; Ogoshi, H. J. Am. Chem. Soc. 1991, 113, 6233.

(33) (a) Hunter, C. A. In Comprehensive Supramolecular Chemistry; Atwood, J. L., Davies, J. E. D., MacNicol, D. D., Vogtle, F., Lehn, J. M., Eds.; Pergamon: Oxford, U.K., 1996. (b) Hunter, C. A. J. Chem. Soc., Chem. Commun. 1991, 749. (c) Brooksby, P. A.; Hunter, C. A.; McQuillan, A. J.; Purvis, D. H.; Rowan, A. E.; Shannon, R. J.; Walsh, R. Angew. Chem., Int. Ed. Engl. 1994, 33, 2489.

(34) Sanders, J. K. M. Pure Appl. Chem. 2000, 72, 2265. 


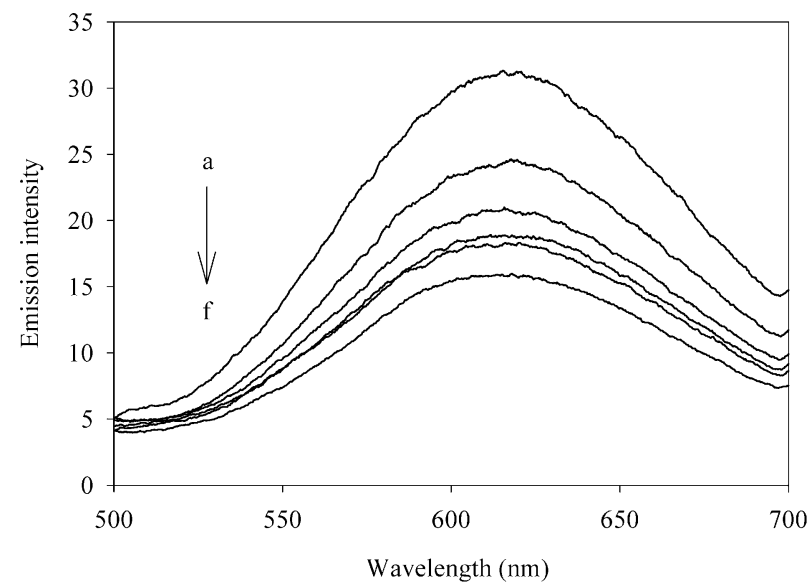

Figure 7. Emission intensity of rectangle $3\left(8 \times 10^{-5} \mathrm{M}\right)$ decreasing with the quencher (1,2-chloranil) concentration in the range of (a) $0 \mathrm{M}$, (b) $2 \times$ $10^{-4} \mathrm{M}$, (c) $3 \times 10^{-4} \mathrm{M}$, (d) $4 \times 10^{-4} \mathrm{M}$, (e) $5 \times 10^{-4} \mathrm{M}$, and (f) $6 \times$ $10^{-4} \mathrm{M}$ in $\mathrm{CH}_{2} \mathrm{Cl}_{2}$.

drawn from the luminescence intensity and lifetime data are linear, the intensity quenching is more efficient than lifetime quenching implying contribution of static quenching. ${ }^{35,36}$ This means that ground-state complex formation between the rectangle and the quencher is possible leading to both static and dynamic quenching. Thus, it is essential to resolve the two contributions to get the rate constants for the dynamic and static quenching processes. To realize the extent of binding between the rectangle and the quencher, the binding constants have been calculated from the modified SternVolmer eq 1 or by the Benesi-Hildebrand method: ${ }^{37,38}$

$$
I_{\mathrm{o}} / I=\left(1+k_{\mathrm{q}} \tau_{\mathrm{o}}[\mathrm{Q}]\right)(1+K[\mathrm{Q}])
$$

Here $I_{\mathrm{o}}$ and $I$ are the emission intensities of rectangles 2-4 in the absence and presence of quenchers, respectively, $\tau_{\mathrm{o}}$ is the excited-state emission lifetime of rectangles, $k_{\mathrm{q}}$ is the quenching rate constant, [Q] is the concentration of quencher, and $K$ is the binding constant. The rate constants obtained from the linear part of the $I_{\mathrm{o}} / I$ vs $[\mathrm{Q}]$ plots at low [Q] are high compared to the values obtained from $\tau_{\mathrm{o}} / \tau$ vs [Q] plots. Further, the binding constants have been calculated from eq 1 and the values for 1,4-naphthaquinone with $\mathbf{2 - 4}$ are 280, 295 , and $1202 \mathrm{M}^{-1}$, respectively, and for 9,10-anthraquinone with $\mathbf{2}$ and $\mathbf{4}$ are 124 and $178 \mathrm{M}^{-1}$, respectively. These results point out that the major contribution for the quenching process comes from static quenching. i.e., quenching after the formation of associated complex between the rectangle and the quencher.

In summary, we have accomplished the synthesis of lightemitting neutral rhenium-based molecular rectangles that possess large cavity sizes having no counterions. By a judicial choice of bridging ligands, we were able to tune the excited-

(35) Canepa, M.; Fox, M. A.; Whitesell, J. K. J. Org. Chem. 2001, 66, 3886.

(36) (a) Prasad, E.; Gopidas, K. R. J. Am. Chem. Soc. 2000, 122, 3191. (b) Smitha, M. A.; Prasad, E.; Gopidas, K. R. J. Am. Chem. Soc. 2001, $123,1159$.

(37) (a) Lakowicz, J. R. Principles of Fluorescence Spectroscopy, 2nd ed.; Kluwer Academic/Plenum Publishers: New York, 1999. (b) White, H. S.; Becker, W. G.; Bard, A. J. J. Phys. Chem. 1984, 88, 1840.

(38) Benesi, M. L.; Hildebrand, J. H. J. Am. Chem. Soc. 1949, 71, 2703. state lifetime of the rectangles from 72 to 495 ns. Fine-tuning of the cavity size and excited-state properties of these molecular rectangles extend their applications to study the excited-state electron-transfer reactions and molecular recognition capabilities.

\section{Experimental Section}

Chemicals. Reagents were used as received. All manipulations were performed under a nitrogen atmosphere using standard Schlenk techniques, and chromatographic separations were carried out in air. Acetone, acetonitrile, dichloromethane, and hexane were dried over $\mathrm{CaH}_{2}$ and were freshly distilled before use. Compounds 4,4'dipyridylacetylene (dpa), 4,4'-dipyridylbutadiyne (dpb), and 1,4bis(4'-pyridylethynyl)benzene (bpeb), were synthesized by published methods. ${ }^{39,40}$ Tetrabutylammonium perchlorate (TBAP) was dried at $100{ }^{\circ} \mathrm{C}$ for $24 \mathrm{~h}$ prior to use.

Instrumentation. IR spectra were recorded on a Perkin-Elmer 882 FT-IR spectrophotometer. UV-visible spectra were obtained on a Hewlett-Packard-8453 spectrophotometer at room temperature in 1-cm quartz cell. The fluorescence spectra were collected by using a Hitachi F-4500 fluorescence spectrophotometer under a nitrogen atmosphere. NMR spectra were recorded on Bruker AC 300 and AMX-400 FT-NMR spectrometers. Elemental analyses were performed using a Perkin-Elmer $2400 \mathrm{CHN}$ elemental analyzer. Electrochemical measurements were recorded on a BAS 100B/W EC Workstation. The electrochemical cell consisted of a three-electrode configuration (glassy-carbon electrode, platinum counter electrode, $\mathrm{Ag} / \mathrm{AgNO}_{3}$ reference electrode). The ferrocene/ ferrocenium couple served as internal reference. The scan rate was $100 \mathrm{mV} / \mathrm{s}$, unless otherwise noted. Cyclic voltammograms were obtained in deoxygenated anhydrous $\mathrm{CH}_{3} \mathrm{CN}$ and $\mathrm{CH}_{2} \mathrm{Cl}_{2}$ with the complexes under investigations $\left(1.0 \times 10^{-3} \mathrm{M}\right)$ and $0.1 \mathrm{M}$ TBAP as supporting electrolyte.

Synthesis of $\left[\left\{\operatorname{Re}(\mathrm{CO})_{3}(\mu \text {-bpy }) \operatorname{Br}\right\}\left\{\operatorname{Re}(\mathrm{CO})_{3}(\mu-\mathrm{pz}) \mathrm{Br}\right\}\right]_{2}(1)$. The details of the synthesis of bimetallic edge $\left\{\operatorname{Re}(\mathrm{CO})_{4} \mathrm{Br}\right\}_{2}(\mu-$ bpy) and rectangle $\left[\left\{\operatorname{Re}(\mathrm{CO})_{3}(\mu \text {-bpy }) \operatorname{Br}\right\}\left\{\operatorname{Re}(\mathrm{CO})_{3}(\mu \text {-pz }) \mathrm{Br}\right\}\right]_{2}(\mathbf{1})$ were given in the previous report. ${ }^{20 \mathrm{a}}$

Synthesis of $\left[\left\{\operatorname{Re}(\mathrm{CO})_{3}(\mu \text {-bpy }) B r\right\}\left\{\operatorname{Re}(\mathrm{CO})_{3}(\mu \text {-dpa }) B r\right\}\right]_{2}(2)$. $\mathrm{A} \mathrm{CH}_{2} \mathrm{Cl}_{2}$ solution of $\mathrm{Me}_{3} \mathrm{NO}(38 \mathrm{mg}, 0.51 \mathrm{mmol})$ was added to a solution of $\left\{\mathrm{Re}(\mathrm{CO})_{4} \mathrm{Br}\right\}_{2}\left(\mu\right.$-bpy) $(228 \mathrm{mg}, 0.25 \mathrm{mmol})$ in $\mathrm{CH}_{2} \mathrm{Cl}_{2}$ $(200 \mathrm{~mL})$ and $\mathrm{CH}_{3} \mathrm{CN}(1 \mathrm{~mL})$. The reaction mixture was stirred at $5{ }^{\circ} \mathrm{C}$ for $3 \mathrm{~h}$ and filtered through Celite. The solvent was removed under vacuum to obtain $\left\{\operatorname{Re}(\mathrm{CO})_{4}(\mathrm{NCMe}) \mathrm{Br}_{2}(\mu\right.$-bpy). The flask containing $\left\{\mathrm{Re}(\mathrm{CO})_{4}(\mathrm{NCMe}) \mathrm{Br}\right\}_{2}\left(\mu\right.$-bpy) was charged with $\mathrm{CH}_{2-}$ $\mathrm{Cl}_{2}$ (200 mL), and a solution of 4,4'-dipyridylacetylene (dpa) (45 $\mathrm{mg}, 0.25 \mathrm{mmol}$ ) in $\mathrm{CH}_{2} \mathrm{Cl}_{2}$ was added dropwise and stirred at 5 ${ }^{\circ} \mathrm{C}$. Completion of the reaction was monitored by IR spectroscopy, and the solvent was removed under vacuum. The product was subjected to chromatographic separation on a silica gel column using a mixture of acetone and $\mathrm{CH}_{2} \mathrm{Cl}_{2}$ (1:99) as eluent to afford the rectangle 2 ( $88 \mathrm{mg}, 0.042 \mathrm{mmol}, 34 \%$ ) as a bright yellow solid. IR $\left(\mathrm{CH}_{2} \mathrm{Cl}_{2}\right): \quad v_{\mathrm{CO}} 2030$ (vs), 1932 (s), 1896 (s) $\mathrm{cm}^{-1} .{ }^{1} \mathrm{H}$ NMR (acetone- $\left.d_{6}\right): \delta 9.04\left(\mathrm{~d},{ }^{3} J=5.9 \mathrm{~Hz}, \mathrm{H}^{3}, 8 \mathrm{H}\right.$, bpy), $8.91\left(\mathrm{~d},{ }^{3} J=\right.$ $\left.6.0 \mathrm{~Hz}, \mathrm{H}^{3}, 8 \mathrm{H}, \mathrm{dpa}\right), 8.02$ (d, $\left.\mathrm{H}^{2}, 8 \mathrm{H}, \mathrm{bpy}\right), 7.70\left(\mathrm{~d}, \mathrm{H}^{2}, 8 \mathrm{H}\right.$, dpa). ${ }^{13} \mathrm{C}$ NMR (acetone- $d_{6}$ ): $\delta$ 196.6, 192.3 (s, 2:1, CO), 156.3 (C ${ }^{3}$, bpy), 155.7 ( $\mathrm{C}^{3}$, dpa), 147.1, 147.0 (C $\mathrm{C}^{1}$, bpy), 133.0, 132.9 (C $\mathrm{C}^{1}$, dpa), 128.8, 128.7 ( $\mathrm{C}^{2}$, bpy), 124.8 ( $\left.\mathrm{C}^{2}, \mathrm{dpa}\right), 93.3,93.1$

(39) (a) Lin, J. T.; Sun, S. S.; Wu, J. J.; Lee, L.; Lin, K. J.; Huang, Y. F. Inorg. Chem. 1995, 34, 2323. (b) Ciana, L. D.; Haim, A. J. Heterocycl. Chem. 1984, 21, 607.

(40) Champness, N. R.; Khlobystov, A. N.; Majuga, A. G.; Schroder, M.; Zyk, N. V. Tetrahedron Lett. 1999, 40, 5413. 
Rajendran et al.

(ethynyl, dpa). Anal. Calcd for $\mathrm{C}_{56} \mathrm{H}_{32} \mathrm{~N}_{8} \mathrm{O}_{12} \mathrm{Br}_{4} \mathrm{Re}_{4} \cdot 4 \mathrm{CH}_{3} \mathrm{COCH}_{3}$ : C, 35.42; H, 2.45; N, 4.86. Found: C, 35.88; H, 2.42; N, 4.74.

Synthesis of $\left[\left\{\operatorname{Re}(\mathrm{CO})_{3}(\mu\right.\right.$-bpy)Br$\}\left\{\operatorname{Re}(\mathrm{CO})_{3}(\mu \text {-dpb)Br }\}\right]_{2}(3)$. The rectangle $\mathbf{3}$ was synthesized by following the previously described procedure for $\mathbf{2}$, using 4,4'-dipyridylbutadiyne (dpb) (46 $\mathrm{mg}, 0.23 \mathrm{mmol}$ ) instead of 4,4'-dipyridylacetylene. Rectangle $\mathbf{3}$ was obtained as a bright yellow solid. Yield: $125 \mathrm{mg}(47 \%)$. IR $\left(\mathrm{CH}_{2-}\right.$ $\mathrm{Cl}_{2}$ ): $v_{\mathrm{CO}} 2029$ (vs), 1931 (s), 1895 (s) $\mathrm{cm}^{-1} .{ }^{1} \mathrm{H}$ NMR (acetone$\left.d_{6}\right): \delta 9.04\left(\mathrm{~d},{ }^{3} J=6.1 \mathrm{~Hz}, \mathrm{H}^{3}, 8 \mathrm{H}, \mathrm{bpy}\right), 8.93\left(\mathrm{~d},{ }^{3} J=5.9 \mathrm{~Hz}\right.$, $\left.\mathrm{H}^{3}, 8 \mathrm{H}, \mathrm{dpb}\right), 8.02$ (d, H$\left.{ }^{2}, 8 \mathrm{H}, \mathrm{bpy}\right), 7.71$ (d, $\left.\mathrm{H}^{2}, 8 \mathrm{H}, \mathrm{dpb}\right) .{ }^{13} \mathrm{C}$ NMR (acetone- $\left.d_{6}\right): \delta$ 196.6, 196.5, 192.2 (s, 1:1:1, CO), 156.3 (C $\mathrm{C}^{3}$, bpy), $155.6\left(\mathrm{C}^{3}, \mathrm{dpb}\right), 147.0$ (C1, bpy), 132.2 (C $\left.\mathrm{C}^{1}, \mathrm{dpb}\right), 129.3$ ( $\mathrm{C}^{2}$, bpy), 124.8 ( $\left.\mathrm{C}^{2}, \mathrm{dpb}\right), 81.5,81.2\left(\mathrm{C}^{2}\right.$, ethynyl, dpb), 80.0, 79.9 $\left(\mathrm{C}^{1}\right.$, ethynyl, dpb). Anal. Calcd for $\mathrm{C}_{60} \mathrm{H}_{32} \mathrm{~N}_{8} \mathrm{O}_{12} \mathrm{Br}_{4} \mathrm{Re}_{4} \cdot 6 \mathrm{CH}_{3}-$ $\mathrm{COCH}_{3}$ : C, 37.93; H, 2.78; N, 4.54. Found: C, 37.56; H, 2.55; N, 4.48 .

Synthesis of $\left[\left\{\operatorname{Re}(\mathrm{CO})_{3}(\mu \text {-bpy }) \operatorname{Br}\right\}\left\{\operatorname{Re}(\mathrm{CO})_{3}(\mu \text {-bpeb }) \mathrm{Br}\right\}\right]_{2}(4)$. The rectangle $\mathbf{4}$ was synthesized by following the previously described procedure for $\mathbf{2}$, using 1,4'-bis(4-pyridylethynyl)benzene (bpeb) (70 mg, $0.25 \mathrm{mmol}$ ) instead of 4,4'-dipyridylacetylene. Rectangle 4 was isolated as a bright yellow solid. Yield: $122 \mathrm{mg}$ (43\%). IR $\left(\mathrm{CH}_{2} \mathrm{Cl}_{2}\right): v_{\mathrm{CO}} 2028$ (vs), 1929 (s), 1894 (s) $\mathrm{cm}^{-1} \cdot{ }^{1} \mathrm{H}$ NMR (acetone- $\left.d_{6}\right): \delta 9.04\left(\mathrm{~d},{ }^{3} J=5.9 \mathrm{~Hz}, \mathrm{H}^{3}, 8 \mathrm{H}, \mathrm{bpy}\right), 8.88(\mathrm{~d}$, ${ }^{3} J=6.6 \mathrm{~Hz}, \mathrm{H}^{3}, 8 \mathrm{H}$, bpeb), $8.03\left(\mathrm{~d}, \mathrm{H}^{2}, 8 \mathrm{H}\right.$, bpy), $7.71(\mathrm{~m}, 8 \mathrm{H}$, phenyl, bpeb), 7.65 (d, $\mathrm{H}^{2}, 8 \mathrm{H}$, bpeb). ${ }^{13} \mathrm{C}$ NMR (acetone- $\left.d_{6}\right)$ : $\delta$ 196.7, 192.3 (s, 2:1, CO), 156.3 (C $\mathrm{C}^{3}$, bpy), 155.4 (C $\mathrm{C}^{3}$, bpeb), 147.0 ( $\mathrm{C}^{1}$, bpy), $134.4\left(\mathrm{C}^{1}\right.$, bpeb), $133.3\left(\mathrm{C}^{2}\right.$, phenyl, bpeb), $128.5\left(\mathrm{C}^{2}\right.$, bpy), 124.7 ( $\mathrm{C}^{2}$, bpeb), 123.6 ( $\mathrm{C}^{1}$, phenyl, bpeb), 97.3, $97.2\left(\mathrm{C}^{2}\right.$, ethynyl, bpeb), 88.8, 88.7 ( $\mathrm{C}^{1}$, ethynyl, bpeb). Anal. Calcd for $\mathrm{C}_{72} \mathrm{H}_{40} \mathrm{~N}_{8} \mathrm{O}_{12} \mathrm{Br}_{4} \mathrm{Re}_{4} \cdot 6 \mathrm{CH}_{3} \mathrm{COCH}_{3}$ : C, 41.22; H, 2.92; N, 4.28. Found: C, 41.22; H, 2.70; N, 4.13.

Excited-State Lifetime Measurements. Excited-state lifetimes of rectangles $\mathbf{1 - 4}$ were measured by a home-constructed timeresolved laser spectrometer. The instrument was equipped with a Quanta Ray GCR-170, pulsed Nd:YAG laser. The third harmonic of the laser $(355 \mathrm{~nm}$, fwhm $=10 \mathrm{~ns})$ was used as excitation source. Emission signals were focused into an ARC SpectraPro-500 double monochromator. The monochromator output was sent into a PMT (Hamamatsu, R928). The signal was digitized by a LeCory 9350A digitizer. Single exponential decays were observed in each case, and the lifetimes obtained were found to be reproducible within $\pm 5 \%$. Decay traces were transferred to a personal computer loaded with the commercial software Origin 4.0. (The luminescence decay profile is shown in the Supporting Information, Figure F3.)

Luminescence Quenching Measurements. The photochemical oxidation/reduction of the molecular rectangles with nitroaromatics, quinones, and aromatic amines was studied by the luminescence quenching technique. The sample solutions were purged with dry nitrogen for 30 min carefully to ensure that there was no change in the volume of the solution. The quenching rate constant, $k_{\mathrm{q}}$, values were determined from the Stern-Volmer equation. ${ }^{41-44}$

Crystallographic Determination. A suitable single crystal with dimensions of $0.35 \times 0.18 \times 0.12 \mathrm{~mm}$ for 1 was selected for indexing and intensity data collection. A total of 1420 frames constituting a hemisphere of X-ray intensity data were collected with a frame width of $0.3^{\circ}$ in $\omega$ and a counting time of $10 \mathrm{~s} /$ frame, using a Bruker SMART CCD diffractometer. The first 50 frames were recollected at the end of data collection to monitor crystal decay. No significant decay was observed. The raw data frames were integrated into SHELX-format reflection files and corrected for Lorentz and polarization effects using the SAINT program and absorption using the SADABS program $\left(T_{\min / \max }=0.2767 /\right.$ $0.4921) .{ }^{45}$ The space group was determined to be $P 2_{1} / c$. Direct methods were used to solve the structure using the SHELX-TL program packages. ${ }^{46}$ All non-hydrogen atoms were refined anisotropically by full-matrix least squares based on $F^{2}$ values on the basis of 7285 independent reflections out of 18370 reflections collected. The maximum and the minimum peaks in final difference maps were 1.195 and -0.838 e $\AA^{-3}$. The largest residual density peak is close to the Re atom. Basic information pertaining to crystal parameters and structure refinement is summarized in Table 1, and selected bond distances and angles are provided in Table 2 .

Acknowledgment. We thank Academia Sinica and the National Science Council of the Republic of China for financial support. We are also grateful to Professor Chong Mou Wang for valuable discussions.

Supporting Information Available: Crystallographic data, isotopic distribution patterns of the $\mathrm{M}^{+}$peaks for $\left\{\operatorname{Re}(\mathrm{CO})_{4} \mathrm{Br}\right\}_{2^{-}}$ ( $\mu$-bpy) and rectangle $\mathbf{1}$, luminescence quenching rate constants of rectangles $\mathbf{2}-\mathbf{4}$ with quenchers, and a molecular modeling diagram of 2-4. This material is available free of charge via the Internet at http://pubs.acs.org.

IC034099X

(41) Rajagopal, S.; Allen Gnanaraj, G.; Mathew, A.; Srinivasan, C. J. Photochem. Photobiol., A: Chem. 1992, 69, 83.

(42) (a) Thanasekaran, P.; Rajendran, T.; Rajagopal, S.; Srinivasan, C. Ramaraj, R.; Ramamurthy, P.; Venkatachalapathy, B. J. Phys. Chem A 1997, 101, 8195. (b) Thanasekaran, P.; Rajagopal, S.; Srinivasan, C. J. Chem. Soc., Faraday Trans. 1998, 94, 3339.

(43) Rajendran, T.; Rajagopal, S.; Srinivasan, C.; Ramamurthy, P. J. Chem. Soc., Faraday Trans. 1997, 93, 3155.

(44) Rajendran, T.; Thanasekaran, P.; Rajagopal, S.; Allen Gnanaraj, G.; Srinivasan, C.; Ramamurthy, P.; Venkatachalapathy, B.; Manimaran, B.; Lu, K. L Phys. Chem. Chem. Phys. 2001, 3, 2063.

(45) SMART/SAINT/ASTRO, release 4.03; Siemens Energy \& Automation, Inc.: Madison, WI, 1995.

(46) Sheldrick, G. M. SHELX-TL; University of Gottingen: Gottingen, Germany. 